\author{
Available online at http://bajas.edu.iq \\ https://doi.org/10.37077/25200860.2019.272 \\ College of Agriculture, University of Basrah
}

Basrah Journal of

Agricultural

Sciences

ISSN 1814 - 5868 Basrah J. Agric. Sci., 32(Spec. Issue 2): 246-255, 2019

E-ISSN: 2520-0860

\title{
Preparation Protein Hydrolysates from Fish by-product and Study Effected on Lettuce (Lactuca sativa L.) Growth, Yield, Quality and Enhanced Salt Tolerance
}

\author{
Haider M.H. Al-Malieky ${ }^{1 *}$ \& Awatif N. Jerry ${ }^{2 * *}$ \\ ${ }^{1}$ Agriculture Directorate of Basrah, Ministry of Agriculture, Iraq. \\ ${ }^{2}$ Department of Horticulture and Landscape Design, College of Agriculture, Basrah, Iraq \\ Corresponding author*e-mail:haidermajd6@gmail.com ;** e-mail: a n \\ Received 19 September 2019; Accepted 18 November 2019; Available online 22 November 2019
}

\begin{abstract}
The experiment was carried out during the winter season 2019-2018 in AlHartha district, Basrah Governorate to study the effects of fish by-product prepared by Alcalase and Flavourzyme enzyme as a foliar application on lettuce (Lactuca sativa L.) yield and quality grown under salinity conditions. Fish by-product protein hydrolysate was spray-applied (3 and $6 \mathrm{ml}^{-\mathrm{L}^{-1}}$ ) additional to control treatment (spraying with water) referred to (T0-T4) at four (S4), six(S6) times after 20 days transplanting at10-day intervals. Randomized Complete Block Design (R.C.B.D.) was used as factorial experiment. Treatment means were compared by using Least Significant Differences (L.S.D.) at a probability of 0.05 . The results showed that spraying with protein hydrolysates had a significant effect on most studied characters compared to control treatment. Results showed that foliar application with (T2) significantly increased the total leaves number, leaves area, carbohydrate, proline, shoot fresh weight of plant, dry matter, total soluble solids (TSS \%) and total yield additional to significantly decreased in nitrate contents, while foliar application with (T4) significantly increased in the plant height and stem height. The results showed that spraying six times (S6) were significant increases in these growth characters comparing with four sprays (S4). The interaction between treatments and spraying number show significantly increased in some characters, the (T2 S6) had the highest value shoot fresh weight $762.5 \mathrm{~g}$ and total yield 17.899 tone.donum $^{-1}$.
\end{abstract}

Keywords: Fish by-product, Protein hydrolysates, Salinity, Yield, Quality, Lettuce.

\section{Introduction}

Lettuce (Lactuca sativa L.) belongs to Asteraceae family, it is one of the most important vegetables in Iraq and other countries. The plant shoot is source of proteins, oils, fibers and minerals such as phosphorus, potassium, zinc and vitamins such as thiamine, riboflavin, niacin, folic acid, B6, C, D vitamins (USDA, 2019). Lettuce leaf extracts can control certain types particularly leukemia cells and breast cancer cells of cancer (Gridling et al., 2010). Salinity is one of the most important abiotic stress factors that affect all vegetable corps, especially in semi-arid and arid regions (Munns \& Tester, 2008) because of small rainfall biostimulants hold a great promise for 
the future of agriculture. These environmentally and friendly natural substances promote vegetative growth, and tolerance of plants to abiotic stresses such as soil salinity, water deficit, and thermal stress, nutrition and crop quality (Chojnacka et al., 2015). Protein hydrolysates are an important group of plant biostimulants that have received growing attention in recent years because of their positive effects on crop performance and contribution to a groecological sustainability. Protein hydrolysates are mixtures of polypeptides, oligopeptides and amino acids that are manufactured from by-products of animals or plant origins protein sources using partial hydrolysis by chemical (acid and alkaline hydrolysis) or enzymatic hydrolysis of a groindustrial (Schaafsma, 2009; Colla et al., 2015).

Several beneficial effects of plant-derived protein hydrolysates on plants including increased nutrient uptake and assimilation and increasing tolerance against abiotic stress (Cavani et al., 2006). The fish by-products contain valuable proteins and essential amino acids. Therefore, hydrolysis of fish protein would be a proper strategy for economic profit (Wisuthiphaet \& Kongruang, 2015).

Several studies have shown the importance of Protein hydrolysate application for improving the growth and production of vegetable crops. Koukounaras et al. (2013) found that applications of an animal-derived hydrolyzed protein Amino16® enhanced both plant height as well as the number of flowers per plant in tomato (Solanum lycopersicum L.). Xu \& Mou (2017) found that the application of fish-derived biostimulants increased the lettuce leaf number from 22 to 28 , shoot fresh and dry weight 59 to $89 \mathrm{~g}$ and 5.5 to $7.5 \mathrm{~g}$.
The aim of this study was to assess the effects of protein hydrolysate from fish byproducts prepared by enzyme hydrolysis using Alcalase and Flavourzyme applied in different concentrations and doses on lettuce growth, yield and quality grown salt stress conditions.

\section{Materials \& Methods}

The experiment was carried out during the winter season 2019-2018 in Al-Hartha district, Basrah Governorate to study the effects of fish by-product protein hydrolysate prepared by Alcalase and Flavourzyme enzyme as a foliar application on growth, yield and quality of lettuce plant under salinity conditions. The chemical and physical characteristics of field soil and irrigation water used in the field reported in table (1). Lettuce cv. Fajr seeds were used, the seeds were cultivated in 209 holes Styrofoam trays at 20/9/2018 in media (peatmous). The seedlings were transplanted to field after 30 days from seed sowing. The soil field preparing and divided into ridge in $3.75 \mathrm{~m}$ of length and distance between them $0.75 \mathrm{~m}$. The cultivation was on both sides of the line, $25 \mathrm{~cm}$ distance between plants, density plants 23466 plant. donum ${ }^{-1}$, each treatment had three replicate.

\section{Preparation of fish by-product protein hydrolysates:}

The hydrolysis processes for fish by-products were carried out using method Chotikachinda et. al. (2018); Klomklaol \& Benjakul (2018). Fish by-products of Marine whitefin wolfherring (Chirocentrus nudus) (head and tails) were purchased from Basrah markets. The byproducts washed with water and dried at 40 ${ }^{\circ} \mathrm{C}$. Then they were ground, the fat was 
Table (1): Chemical and physical properties of the soil and irrigation water used in field.

\begin{tabular}{|c|c|}
\hline \multicolumn{2}{|c|}{ Soil Chemical } \\
\hline E.C. $\left(\mathrm{ds} . \mathrm{m}^{-1}\right)$ & 10.22 \\
\hline $\mathrm{pH}$ & 7.69 \\
\hline Total nitrogen $\left(\mathrm{g} \cdot \mathrm{kg}^{-1}\right)$ & 0.75 \\
\hline Phosphorus (mg.kg-1). & 2.46 \\
\hline Potassium (mg.kg $\left.{ }^{-1}\right)$ & 15.51 \\
\hline Organic matter $(\%)$ & 1.64 \\
\hline \multicolumn{2}{|c|}{ Soil Structure } \\
\hline Sand $(\%)$ & 11 \\
\hline Silt (\%) & 69 \\
\hline Clay (\%) & 20 \\
\hline Texture Class & Silty clay \\
\hline \multicolumn{2}{|c|}{ Irrigation Water } \\
\hline E.C. $\left(\mathrm{ds} . \mathrm{m}^{-1}\right)$ & 6.48 \\
\hline $\mathrm{pH}$ & 7.39 \\
\hline
\end{tabular}

removed from powder according to Qi et al., (2015). The fish by-products were mixed with water at ratio 1:6. The mixed was heated at $85^{\circ} \mathrm{C}$ for 10 min (Guerard et al., 2002).

The fish by-products were hydrolysate using Alcalase and Flavourzyme under optimal conditions of each: Alcalase $(\mathrm{pH} 8$, $\left.50^{\circ} \mathrm{C}\right)$ and Flavourzyme $\left(\mathrm{pH} 7,50^{\circ} \mathrm{C}\right)$ for 6 hours. Enzyme and substrate ratio of $0.1 \%$. The hydrolysis degree was monitored during the process, and the reaction was stopped by inactivating the enzyme $\left(90^{\circ} \mathrm{C} / 10 \mathrm{~min}\right)$. The hydrolysis was centrifuged at 4000rpm for 20 min and concentration by rotary evaporator. The study included ten treatments which were the combination of five treatments are control (T0), Tow concentrations from hydrolysate using Alcalase T1:3 ml.1 $\mathrm{l}^{-1}$ T2: $6 \mathrm{ml}^{-\mathrm{l}^{-1}}$ and Flavourzyme T3: $3 \mathrm{ml}^{-\mathrm{l}^{-1}}$ and T4:6 $\mathrm{ml}^{-\mathrm{l}^{-1}}$. Plants were sprayed with hydrolyzed protein treatments four times (S4) and six times (S6) during the growing season. Treatments were applied to start at 20 days after transplant at10- day intervals. Head lettuce was harvested at the marketable stage.
Harvesting was carried out from 10/1 to $12 / 2 / 2018$. Plant height $(\mathrm{cm})$, stem height $(\mathrm{cm})$, total leaf number, plant leaf area $\left(\mathrm{cm}^{2}\right.$. plant $\left.^{-1}\right)$, shoot fresh weight $(\mathrm{g})$, dry matter $(\mathrm{g})$ and total yield (tone. donum ${ }^{-1}$ ) were recorded at harvest. The nitrate was determined according to Cataldo et al. (1975) carbohydrate determined by using methods Dubois et al. (1956). Proline was determined using the method of Bates et al. (1973). and TSS determined as described by AOAC (2012).

\section{Characterization of fish by-products protein hydrolysates}

Total amino acids in fish by-product protein hydrolysates were determined by sing HighPerformance Liquid Chromatography (HPLC), according to Levin \& Grushka (1985). Organic matter was determined by using method Ben-Dor \& Banin (1989).

The Randomized Complete Block Design (R.C.B.D.) was used factorial experiment with three replications for each parameter. 
Table (2): Total amino acids and organic matter in fish by-product protein hydrolysates (\%) using enzymes Alcalase and Flavourzyme.

\begin{tabular}{|c|c|c|c|c|c|}
\hline \multicolumn{6}{|c|}{ Amino acid \% } \\
\hline \multicolumn{4}{|c|}{ Alcalase } & \multicolumn{2}{|c|}{ Flavourzyme } \\
\hline Asp & 1.48 & Trp & 3.73 & Asp 1.51 & Trp 1.12 \\
\hline Glu & 22.72 & Val & 7.42 & $\begin{array}{ll}\text { Glu } 20.70 \\
\end{array}$ & $\begin{array}{ll}\text { Val } & 7.09\end{array}$ \\
\hline Gly & 15.79 & Met & 1.07 & Gly 14.13 & Met 1.58 \\
\hline Ser & 14.45 & Cys & 1.80 & Ser 15.63 & Cys 4.68 \\
\hline Ala & 5.18 & Lys & 0.72 & Ala 5.05 & Lys 1.54 \\
\hline His & 4.07 & Arg & 3.38 & His 0.17 & Arg 1.32 \\
\hline Thr & 0.05 & Ile & 3.71 & Thr 4.89 & Ile 2.35 \\
\hline Pro & 5.70 & Leu & 7.02 & Pro 5.41 & Leu 6.00 \\
\hline Phe & 1.46 & & & Phe 3.56 & \\
\hline & Tota & acids & $9.75 \%$ & Total ami & $96.73 \%$ \\
\hline & Total & matte & $87.2 \%$ & Total org. & $84.07 \%$ \\
\hline
\end{tabular}

The treatment means were compared with (L.S.D.) test at 0.05. The data were analyzed by using the statistical program Genstat (version 7.2).

\section{Results \& Discussion}

Table (3) displayed that the T2 and T4 had a significant effects on vegetative growth. Plant height and stem height of T4 plants were $35.05 \mathrm{~cm}$ and $19.18 \mathrm{~cm}$ respectively. T0 treatment recorded the 24.88 and $11.34 \mathrm{~cm}$ respectively. Significant increases were found in the total leaf number and plant leaf area 58.87 and $424.94 \mathrm{~cm}^{2}$. plant ${ }^{-1}$ respectively. of (T2) compared with T0 treatment had the lowest value of total leaf number 39.65 leave and leaves area $214.85 \mathrm{~cm}^{2}$. plant $^{-1}$.

The results showed that spraying six times (S6) significantly increases growth parameters comparing with four sprays (S4).

The interaction between treatments and spraying numbers shows significantly increased in leaf area, the (T2 S6) had the highest leaf area value $445.70 \mathrm{~cm}^{2}$. plant ${ }^{-1}$,

\section{Statistical analysis}

while the (T0S4) treatment had the lowest value $211.34 \mathrm{~cm}^{2}$. plant ${ }^{-1}$. The positive effect of protein hydrolysates low molecular weight peptides and amino acids stimulate plant growth parameters through stimulation nitrogen uptake and increased leaf $\mathrm{N}$ contents plant biomass (Colla et al., 2014; 2015). As well as the regulation of nitrogen uptake and the enzymes activity of TCA cycle (Colla et al., 2015; Nardi et al., 2016). Protein hydrolysates are also stimulating plants carbon and nitrogen metabolism (Colla et al., 2017).

The foliar application of protein hydrolysates can induce plant defense responses, thus increasing plant tolerance for various abiotic stresses. Also, Protein hydrolysates have chelating activities that reduce the impact of different stresses on plant growth (Colla et al., 2014). In the present study, the protein hydrolysates preparation from fish by-products contains several amino acids such as Glutamic acid, Glycine, 
Al-Malieky \& Jerry / Basrah J. Agric. Sci., 32(Spec. Issue 2): 246-255, 2019

Table (3): Effect of foliar application of fish by-products protein hydrolysates and number of sprays on some vegetative growth characters of lettuce.

\begin{tabular}{ccccc}
\hline Treatments & $\begin{array}{c}\text { Plant height } \\
(\mathrm{cm})\end{array}$ & $\begin{array}{c}\text { Stem } \\
\text { height }(\mathrm{cm})\end{array}$ & $\begin{array}{c}\text { Total Leaf } \\
\text { number }\end{array}$ & $\begin{array}{c}\text { Leaf area } \\
\left(\mathrm{cm}^{2} \cdot \text { plant }^{-1}\right)\end{array}$ \\
\hline FT0 & $24.88 \pm 0.60$ & $11.34 \pm 0.43$ & $39.65 \pm 0.20$ & $214.85 \pm 2.87$ \\
\hline T1 & $29.42 \pm 1.10$ & $17.30 \pm 1.00$ & $50.50 \pm 0.95$ & $337.09 \pm 17.79$ \\
\hline T2 & $30.72 \pm 1.31$ & $17.80 \pm 1.38$ & $58.87 \pm 0.65$ & $424.94 \pm 16.95$ \\
\hline T3 & $27.43 \pm 0.62$ & $14.56 \pm 0.51$ & $46.33 \pm 1.63$ & $296.44 \pm 20.83$ \\
\hline T4 & $35.05 \pm 0.36$ & $19.18 \pm 1.53$ & $53.03 \pm 1.57$ & $360.88 \pm 21.09$ \\
\hline LSD 0.05 & 1.364 & 0.801 & 1.403 & 12.41 \\
\hline S4 & $28.51 \pm 3.16$ & $14.97 \pm 2.11$ & $48.44 \pm 5.75$ & $307.35 \pm 58.8$ \\
\hline S6 & $30.49 \pm 3.09$ & $17.30 \pm 3.02$ & $50.90 \pm 6.07$ & $346.32 \pm 69.1$ \\
\hline LSD 0.05 & 0.862 & 0.507 & 0.887 & 7.85 \\
\hline
\end{tabular}

\begin{tabular}{cccccc}
\hline \multicolumn{5}{c}{ Fish by-products } & protein hydrolysates $\times$ Number of sprays \\
\hline T0 & S4 & $24.13 \pm 0.60$ & $10.83 \pm 0.22$ & $39.40 \pm 0.74$ & $211.34 \pm 1.45$ \\
\cline { 2 - 6 } & S6 & $25.63 \pm 0.34$ & $11.89 \pm 0.40$ & $39.90 \pm 0.32$ & $218.37 \pm 0.67$ \\
\hline T1 & S4 & $28.07 \pm 0.71$ & $16.40 \pm 0.34$ & $49.33 \pm 1.08$ & $315.30 \pm 8.62$ \\
\cline { 2 - 6 } & S6 & $30.77 \pm 1.42$ & $18.86 \pm 0.38$ & $51.66 \pm 1.08$ & $358.88 \pm 8.96$ \\
\hline T2 & S4 & $29.10 \pm 0.60$ & $16.10 \pm 0.39$ & $58.06 \pm 0.68$ & $404.17 \pm 6.53$ \\
\cline { 2 - 6 } & S6 & $32.33 \pm 0.57$ & $19.49 \pm 0.70$ & $59.67 \pm 0.40$ & $445.70 \pm 3.19$ \\
\hline T3 & S4 & $26.67 \pm 1.08$ & $13.93 \pm 0.28$ & $44.33 \pm 1.08$ & $270.92 \pm 14.91$ \\
\cline { 2 - 6 } & S6 & $28.20 \pm 0.60$ & $15.20 \pm 0.37$ & $48.33 \pm 1.08$ & $321.96 \pm 6.90$ \\
\hline T4 & S4 & $34.60 \pm 0.86$ & $17.30 \pm 0.36$ & $51.10 \pm 0.60$ & $335.04 \pm 4.25$ \\
\cline { 2 - 6 } & S6 & $35.50 \pm 0.64$ & $21.06 \pm 0.89$ & $54.96 \pm 0.67$ & $386.71 \pm 5.60$ \\
\hline LSD 0.05 & N.S & N.S & N.S & 17.56
\end{tabular}

*T0: Control (untreated) T1: Protein hydrolysate 3 ml. $\mathrm{l}^{-1}$ prepared by Alcalase T2: Protein hydrolysate prepared by Alcalase at $6 \mathrm{ml.l}^{-1}$, T3: Protein hydrolysate prepared by Flavourzyme at 3m.l ${ }^{-1}$, T4: Protein hydrolysate prepared by Flavourzyme at $6 \mathrm{ml}^{-1}{ }^{-1}$, S4; Plants were sprayed with hydrolyzed protein treatments four times, S6; Plants were sprayed with hydrolyzed protein treatments six times.The significant at $P<0.05$ level. \pm means Standard deviation (S.D.) ; $\mathbf{n = 3}$ and Not significant (N.S.) .

Serene, Alanine, Proline and tryptophan as in the table (2), which stimulate photosynthesis, hormone balance and vegetative growth (Zhao, 2014). The results agreed with those of Lucini et al. (2015), who found that foliar application of protein hydrolysates improved the vegetative growth of lettuce plants. Also, Xu \& Mou (2017) observed that the protein hydrolysates treated lettuce plants significantly increased vegetative growth. 
Table (4) revealed a significant difference among the treatments, the spraying (T2) treatment recorded the highest carbohydrate and proline content $75.31 \mathrm{mg}^{-\mathrm{g}^{-1}}$ and 19.84 $\mu \mathrm{mol} . \mathrm{g}^{-1}$ respectively, while (T2) had the lowest nitrate content $0.309 \mathrm{mg} \cdot \mathrm{g}^{-1}$ compared with (T0) treatment which gave the lowest value carbohydrate and proline content 34.57 $\mathrm{mg} . \mathrm{g}^{-1}$ and $13.35 \mu \mathrm{mol} . \mathrm{g}^{-1}$ respectively, while (T0) gave the highest value of nitrate 0.394 $\mathrm{mg} \cdot \mathrm{g}^{-1}$.

Spraying six times (S6) significantly increased carbohydrate, proline and chlorophyll contents compared with four times (S4), while it decreased nitrate content. The interaction between treatments and spraying numbers shows significantly decreased in nitrate content, It is noticeable that treatment T2S6 produced lowest value of nitrate content $0.306 \mathrm{mg}$. $\mathrm{g}^{-1}$ compared with (T0S4) treatment which had the highest value of nitrate $0.391 \mathrm{mg}^{-\mathrm{g}^{-1}}$. The protein hydrolysate used in this study contained percentage of glycine and proline (table 2) that may promotes the accumulation of carbohydrate,

Table (4): Effect of foliar application of fish by-products protein hydrolysates and number of sprays on nitrate, carbohydrate and proline of lettuce leaves.

\begin{tabular}{|c|c|c|c|c|}
\hline \multicolumn{2}{|c|}{ Treatments } & $\begin{array}{c}\text { Nitrate } \\
\left(\mathrm{mg} \cdot \mathrm{g}^{-1} \mathrm{fw}\right)\end{array}$ & $\begin{array}{c}\text { Carbohydrate (mg.g } \\
\left.{ }^{-} \mathrm{dw}\right)\end{array}$ & $\begin{array}{l}\text { Proline }\left(\mu \mathrm{mol} . \mathrm{g}^{-}\right. \\
\qquad\left({ }^{1} \mathrm{dw}\right)\end{array}$ \\
\hline \multicolumn{5}{|c|}{ Fish by-products protein hydrolysates $\left(\mathrm{ml}^{-\mathrm{l}^{-1}}\right)$} \\
\hline \multicolumn{2}{|c|}{ T0 } & $0.394 \pm 0.001$ & $34.57 \pm 2.61$ & $13.35 \pm 0.13$ \\
\hline \multicolumn{2}{|c|}{$\mathrm{T} 1$} & $0.357 \pm 0.004$ & $56.20 \pm 2.58$ & $17.09 \pm 0.21$ \\
\hline \multicolumn{2}{|c|}{$\mathrm{T} 2$} & $0.309 \pm 0.002$ & $75.31 \pm 2.63$ & $19.84 \pm 0.59$ \\
\hline \multicolumn{2}{|c|}{ T3 } & $0.377 \pm 0.003$ & $46.69 \pm 1.85$ & $16.01 \pm 0.45$ \\
\hline \multicolumn{2}{|c|}{ T4 } & $0.346 \pm 0.003$ & $61.59 \pm 1.42$ & $18.14 \pm 0.35$ \\
\hline \multicolumn{2}{|c|}{ LSD 0.05} & 0.015 & 3.13 & 0.81 \\
\hline \multicolumn{5}{|c|}{ Number of sprays } \\
\hline \multicolumn{2}{|c|}{ S4 } & $0.359 \pm 0.02$ & $52.15 \pm 12.6$ & $16.46 \pm 1.84$ \\
\hline \multicolumn{2}{|c|}{ S6 } & $0.354 \pm 0.03$ & $57.59 \pm 12.4$ & $17.31 \pm 2.12$ \\
\hline \multicolumn{2}{|c|}{ LSD 0.05} & 0.003 & 1.98 & 0.51 \\
\hline \multicolumn{5}{|c|}{ Fish by-products protein hydrolysates $\times$ Number of sprays } \\
\hline \multirow[t]{2}{*}{ T0 } & S4 & $0.391 \pm 0.002$ & $31.37 \pm 0.84$ & $13.19 \pm 0.17$ \\
\hline & S6 & $0.396 \pm 0.001$ & $37.78 \pm 2.39$ & $13.51 \pm 0.27$ \\
\hline \multirow[t]{2}{*}{$\mathrm{T} 1$} & $\mathrm{~S} 4$ & $0.362 \pm 0.003$ & $53.04 \pm 1.68$ & $16.83 \pm 0.44$ \\
\hline & S6 & $0.351 \pm 0.003$ & $59.36 \pm 1.58$ & $17.36 \pm 0.47$ \\
\hline \multirow[t]{2}{*}{$\mathrm{T} 2$} & S4 & $0.312 \pm 0.04$ & $72.08 \pm 0.27$ & $19.11 \pm 0.67$ \\
\hline & S6 & $0.306 \pm 0.003$ & $78.54 \pm 2.15$ & $20.56 \pm 0.81$ \\
\hline \multirow[t]{2}{*}{$\mathrm{T} 3$} & S4 & $0.381 \pm 0.002$ & $44.42 \pm 3.45$ & $15.46 \pm 0.40$ \\
\hline & S6 & $0.373 \pm 0.002$ & $48.96 \pm 1.26$ & $16.56 \pm 0.62$ \\
\hline \multirow[t]{2}{*}{$\mathrm{T} 4$} & S4 & $0.350 \pm 0.001$ & $59.85 \pm 0.26$ & $17.70 \pm 0.28$ \\
\hline & S6 & $0.342 \pm 0.003$ & $63.33 \pm 1.94$ & $18.57 \pm 0.63$ \\
\hline \multicolumn{2}{|c|}{ LSD 0.05} & 0.002 & N.S & N.S \\
\hline
\end{tabular}


regulate proline biosynthetic pathway enzymes. While, the decrease of nitrate contents might be caused by the role of amino acids on nitrate uptake the regulation of several processes and metabolic pathways of plant nitrogen such as nitrate and nitrite reduction and glutamic synthesis activities (Liu et al., 2008 a, b).

Similar results were observed by Rouphael et al. (2017) who found an increase in the accumulation of proline of lettuce contents when foliar sprayed with protein hydrolysates "Trainer". Tsouvaltzis et al. (2014) observed that amino acids treatment reduced the nitrate content of lettuce by $29 \%$, while Genc \&
Atici (2019) obtained that the protein hydrolysate preparation from chicken feather treatment could enhance the free sugars contents in wheat plants.

Result in table (5) indicated significant difference among the treatments, The spraying T2 and T4 treatment influenced most studies characteristics, but the highest significant increased obtained from (T2) in shoot fresh weight 756.1 g. dry matter $7.09 \%$, TSS $4.50 \%$ and total yield 17.747 ton. donum ${ }^{1}$ compared with (T0) treatment which gave the lowest value of shoot fresh weight 452.0 g, dry matter $4.94 \%$, TSS $2.92 \%$ and total yield 10.606 tone. donum ${ }^{-1}$.

Table (5): Effect of foliar application of fish by-products protein hydrolysates and number of sprays on yield and some quality parameters.

\begin{tabular}{|c|c|c|c|c|c|}
\hline \multicolumn{2}{|c|}{ Treatments } & $\begin{array}{l}\text { Shoot fresh weight } \\
(\mathrm{g})\end{array}$ & $\begin{array}{l}\text { Dry matter } \\
(\%)\end{array}$ & $\begin{array}{c}\text { Total soluble solid (TSS) } \\
(\%)\end{array}$ & $\begin{array}{c}\text { Total yield } \\
\text { (tone. donum }{ }^{-1} \text { ) }\end{array}$ \\
\hline \multicolumn{6}{|c|}{ Fish protein by-products hydrolysates $\left(\mathrm{ml} . \mathrm{l}^{-1}\right)$} \\
\hline \multicolumn{2}{|c|}{ T0 } & $452.0 \pm 11.7$ & $4.94 \pm 0.09$ & $2.92 \pm 0.17$ & $10.606 \pm 0.27$ \\
\hline \multicolumn{2}{|c|}{ T1 } & $571.2 \pm 9.7$ & $6.31 \pm 0.32$ & $3.98 \pm 0.17$ & $13.404 \pm 0.22$ \\
\hline \multicolumn{2}{|c|}{$\mathrm{T} 2$} & $756.1 \pm 5.3$ & $7.09 \pm 0.29$ & $4.50 \pm 0.11$ & $17.747 \pm 0.12$ \\
\hline \multicolumn{2}{|c|}{ T3 } & $498.5 \pm 11.5$ & $5.88 \pm 0.33$ & $3.83 \pm 0.16$ & $11.699 \pm 0.27$ \\
\hline \multicolumn{2}{|c|}{$\mathrm{T} 4$} & $629.0 \pm 6.3$ & $6.49 \pm 0.28$ & $4.23 \pm 0.17$ & $14.761 \pm 0.14$ \\
\hline \multicolumn{2}{|c|}{ LSD 0.05} & 14.1 & 0.216 & 0.294 & 0.331 \\
\hline \multicolumn{6}{|c|}{ Number of sprays } \\
\hline \multicolumn{2}{|c|}{ S4 } & $570.5 \pm 97.5$ & $5.81 \pm 0.58$ & $3.69 \pm 0.50$ & $13.387 \pm 2.56$ \\
\hline \multicolumn{2}{|c|}{ S6 } & $592.3 \pm 94.2$ & $6.47 \pm 0.72$ & $4.08 \pm 0.47$ & $13.900 \pm 2.21$ \\
\hline \multicolumn{2}{|c|}{ LSD 0.05} & 8.93 & 0.136 & 0.186 & 0.209 \\
\hline \multicolumn{6}{|c|}{ Fish protein hydrolysates $\times$ Number of spray $s$} \\
\hline \multirow[t]{2}{*}{ T0 } & $\mathrm{S} 4$ & $437.6 \pm 3.5$ & $4.81 \pm 0.15$ & $2.70 \pm 0.14$ & $10.267 \pm 0.08$ \\
\hline & S6 & $466.4 \pm 6.8$ & $5.06 \pm 0.11$ & $3.13 \pm 0.17$ & $10.944 \pm 0.15$ \\
\hline \multirow[t]{2}{*}{$\mathrm{T} 1$} & $\mathrm{~S} 4$ & $559.3 \pm 14.7$ & $5.91 \pm 0.19$ & $3.77 \pm 0.17$ & $13.123 \pm 0.34$ \\
\hline & S6 & $583.2 \pm 10.8$ & $6.71 \pm 0.09$ & $4.20 \pm 0.21$ & $13.685 \pm 0.25$ \\
\hline \multirow[t]{2}{*}{$\mathrm{T} 2$} & $\mathrm{~S} 4$ & $749.8 \pm 11.2$ & $6.73 \pm 0.06$ & $4.37 \pm 0.10$ & $17.595 \pm 0.26$ \\
\hline & S6 & $762.5 \pm 8.3$ & $7.46 \pm 0.06$ & $4.63 \pm 0.31$ & $17.899 \pm 0.19$ \\
\hline \multirow[t]{2}{*}{ T3 } & $\mathrm{S} 4$ & $484.4 \pm 6.7$ & $5.47 \pm 0.33$ & $3.63 \pm 0.11$ & $11.368 \pm 0.16$ \\
\hline & S6 & $512.6 \pm 1.5$ & $6.28 \pm 0.03$ & $4.03 \pm 0.11$ & $12.030 \pm 0.03$ \\
\hline \multirow[t]{2}{*}{$\mathrm{T} 4$} & $\mathrm{~S} 4$ & $621.3 \pm 6.4$ & $6.14 \pm 0.02$ & $4.00 \pm 0.10$ & $14.580 \pm 0.15$ \\
\hline & S6 & $636.8 \pm 2.8$ & $6.83 \pm 0.02$ & $4.43 \pm 0.11$ & $14.942 \pm 0.06$ \\
\hline \multicolumn{2}{|c|}{ LSD 0.05} & 19.97 & 0.305 & N.S & 0.468 \\
\hline
\end{tabular}


The results showed that spraying six times (S6) significantly increases in characters compared with four sprays (S4). The interaction between treatments and spraying number shows significantly affected all studying characteristics except TSS. The (T2S6) had the highest values of shoot fresh weight $762.5 \mathrm{~g}$, dry matter $7.46 \%$, TSS $4.63 \%$ and total yield 17.899 tone. donum ${ }^{-1}$ compared with (TOS4) that had the lowest values $437.6 \mathrm{~g}, 4.81 \%$, $2.70 \%$, and 10.267 tone. donum ${ }^{-1}$.

Protein hydrolysates may positively affect plants due to amino acids (table 2) acting on an increase in vegetative growth. Such as leaf number and leaf area, photosynthesis, chlorophyll content, protein synthesis and mechanisms involved in abiotic stress resistance (Cavani et al., 2006). As well as chelating effects and hormone-like activity (Colla et al., 2014) . The results agree with the study of $\mathrm{Xu} \&$ Mou (2017) on the application of fishderived protein hydrolysates, which significantly increased fresh weight lettuce crop. Tarantino et al. (2015) observed higher dry matter in pepper, cauliflower and fennel crops when, treated with biostimulant "Siapton". Significant improvement in TSS was observed by Tsouvaltzis et al. (2014) when lettuce plants treated with amino acids. Polo \& Mata (2018) observed increased tomato yield when peptone treated plants.

\section{Conclusions}

The protein hydrolysate derived from fish by-product using either Alcalase or Flavourzyme was effective in improving the growth, yield and quality of lettuce under salinity conditions. protein hydrolysis applied at T2 and T4 treatment gave the highest value of shoot fresh weight and total yield compared with T0. Spraying six times (S6) significantly increases in most parameters compared with four sprays (S4). protein hydrolysates is possible used for sustainable production of lettuce.

\section{Acknowledgments}

The authors want to thank the Department of Horticulture and Landscape Design, College of Agriculture, University of Basrah for supporting.

\section{References}

AOAC. (2012). Association of Official Analytical Chemistry. 19. ed. Gaithersburg: :3000pp.

Bates, L.S.; Waldren, R.P. \& Teare, I.D. (1973). Rapid determination of free proline for water stress studies. Plant Soil, 39: 205-207.

Ben-Dor, E. \& Banin, A. (1989). Determination of organic matter content in arid zone soils using a simple "Losson-Ignition" method. Communications Soil Sci. Plant Anal., 20: 1675-1695.

Cataldo, D.A.; Maroon, M. \& Schrader, L.E. (1975). Rapid colorimetric determination of nitrate in plant-tissue by nitration of salicylic-acid. Commun. Soil Science and Plant Analysis, 6(1): 71-80.

Cavani, L.; Ter- Halle, A.; Richar, D. C. \& Ciavatta, C. (2006). Photosensitizing properties of protein hydrolysate-based fertilizers. J. Agric. Food Chem., 54: 9160- 9167.

Chojnacka, K.; Michalak, I.; Dmytryk, A.; Wilk, R. \& Gorecki, H. (2015). Innovative natural plant growth biostimulants. 451-489. In Sinha, S.; Pant, K.K.; Bajpai S. \& Govil, J.N. (Eds.). Fertilizer Technology: II Biofertilizer. Houston, TX: Studium Press LLC: 268pp. 
Chotikachinda, R.; Tantikitti, C.; Benjakul, S. \& Rustad, T. (2018). Tuna viscera hydrolysate products prepared by different enzyme preparations improve the feed intake and growth of Asian seabass, Lates calcarifer, fed total fishmeal replacement diets. Songklanakarin J. Sci. Technol., 40(1): 167-177

Colla, G.; Rouphael, Y.; Canaguier, R.; Svecova, E. \& Cardarelli, M. (2014). Biostimulant action of a plant-derived protein hydrolysate produced through enzymatic hydrolysis. Front Plant Sci., 5(448): 1-6.

Colla, G.; Nardi, S.; Cardarelli, M.; Ertani, A.; Lucini,L.; Canaguier, R. \& Rouphael, Y. (2015). Protein hydrolysates as biostimulants in horticulture. Scientia Horticulturae, 196: 28-38.

Colla, G.; Hoagland, L.; Ruzzi, M.; Cardarelli, M.; Bonini, P.; Canaguier, R. \& Rouphael, Y. (2017) .Biostimulant action of protein hydrolysates: Unraveling their effects on plant physiology and microbiome. Front. Plant Sci., 8: 2202. doi: 10.3389/fpls.2017. 02202.

Dubois, M.K.; Crilles, K.A.; Hamilor, J.K.; Rebers, D.A. \& Smith, F.(1956). Colorimetric method for determination of sugars and related substances. Anal. Chem., 28: 350-365.

Genc, E. \& Atici, O. (2019). Chicken feather protein hydrolysate as a biostimulant improves the growth of wheat seedlings by affecting biochemical and physiological parameters. Turkish J. Bot., 43: 67-79.

Gridling, M.; Popescu. B.; Kopp, B.; Wagner, K.H.; Krenn, L. \& Krupitza, G. (2010). Anti-leukaemic effects of two extract types of Lactuca sativa correlate with the activation of Chk2, induction of p21, down regulation of cyclin D1 and acetylation of alpha-tubulin. Oncol. Rep., 23(4): 1145-1151.

Guerard, F.; Guimas, L. \& Binet, A. (2002). Production of tuna waste hydrolysates by a commercial neutral protease preparation. J. Mol. Catalysis B: Enzym., 19: 489-498.

Klomklao1, S. \& Benjakul, S. (2018). Protein hydrolysates prepared from the viscera of skipjack tuna (Katsuwonus pelmamis): Antioxidative activity and functional properties. Turkish J. Fish. Aquat. Sci., 18: 69-79.

Koukounaras, A.; Tsouvaltzis, P. \& Siomos, A. (2013). Effect of root and foliar application of amino acids on the growth and yield of greenhouse tomato in different fertilization levels. J. Food Agric. Environ., 11(2): 644-648.

Levin, S. \& Grushka, E. (1985). Reversedphase liquid chromatographic separation of amino acids with aqueous mobile phases containing copper ions and alkylsulfonates. Anal. Chem., 57: 18301835.

Liu, X.Q.; Chen, H.Y.; Ni, Q.X. \& Lee, K.S. (2008a). Evaluation of the role of mixed amino acids in nitrate uptake and assimilation in leafy radish by using ${ }^{15} \mathrm{~N}$ labeled nitrate. Agric. Sci. Chin., 7: 1196-1202 .

Liu, X.Q.; Ko, K.Y.; Kim, S.H. \& Lee, K.S. (2008b). Effect of amino acid fertilization on nitrate assimilation of leafy radish and soil chemical properties in high nitrate soil. Commun. Soil Sci. Plant Anal., 39: 269-281.

Lucini, L.; Rouphael, Y.; Cardarelli, M.; Canguier, R.; Kumar, P. \& Colla G. 
(2015). The effect of a plant-derived biostimulant on metabolic profiling and crop performance of lettuce grown under saline conditions. Sci. Hortic., 182: 124133.

Munns, R. \& Tester, M. (2008). Mechanisms of salinity tolerance. Ann. Rev. Plant Biol., 59: 651-681.

Nardi, S.; Pizzeghello, D.; Shiavon, M. \& Ertani, A. (2016). Plant biostimulants :Physiological responses induced by protein hydrolyzed-based products and humic substances in plant metabolism. Sci. Agric., 73: 18-23.

Polo, J. \& Mata, P. (2018). Evaluation of a biostimulant (Pepton) based in enzymatic hydrolyzed animal protein in comparison to seaweed extracts on root development, vegetative growth, flowering, and yield of gold cherry tomatoes grown under low stress Ambient Field Conditions. Front. Plant Sci., 8: 2261: 1-8.

Qi, J.; Yokoyama, W.; Masamba, K.G.; Majeed, H.; Zhong, F. \& Li, Y. (2015). Structural and physicochemical properties of insoluble rice bran fiber fiberi effect of acid -base induced modifications. J. RSC. Adv., 97(5): 79915-79923.

Rouphael, Y.; Cardarelli, M.; Bonini, P. \& Colla, G. (2017). Synergistic action of a microbial-based biostimulant and a plant derived-protein hydrolysate enhances lettuce tolerance to alkalinity and salinity. Front. Plant Sci., 8: 131.

Schaafsma, G. (2009). Safety of protein hydrolysates, fractions thereof and bioactive peptides in human nutrition. Eur. J. Clin. Nutr., 63(10): 1161-1168.

Tarantino, E.; Disciglio, G.; Frabboni, L.; Libutti, A.; Gatta, G.; Gagliaridi, A. \& Tarantino, A. (2015). Effects of biostimulant application on qualiquantitative characteristics of cauliflower, pepper and fennel crops under organic and conventional fertilization. Int. J. Agric. Biosys. Eng., 9(7): 734-738.

Tsouvaltzis, P.; Koukounaras, A. \& Siomos, A.S. (2014). Application of amino acids improves lettuce crop uniformity and inhibits nitrate accumulation induced by the supplemental inorganic nitrogen fertilization. Int. J. Agric. Biol., 16: 951955.

United States Department of Agriculture (USDA) (2019). National Nutrient Database for Standard Reference Release.:https://ndb.nal.usda.gov/ndb/fo ods/show/3001

Wisuthiphaet, N. \& Kongruang, S. (2015). Production of fish protein hydrolysates by acid and enzymatic hydrolysis. J. Med. Bioeng., 4(6): 466-470.

$\mathrm{Xu}$, C. \& Mou, B. (2017). Drench application of fish-derived protein hydrolsates affects lettuce growth, chlorophyll content and gas exchange. Hort. Technol., 27(4): 539-543.

Zhao, Y. (2014). Auxin biosynthesis. Arabidopsis Book Am. Soc. Plant Biol., 12: e 0173. 10.1199/tab.0173. 